\title{
KINDERGARTEN TEACHER'S ABILITY IN TEACHING MATH IN TK PEMBINA OF PEKANBARU CITY
}

\author{
Yeni Solfiah
}

\begin{abstract}
Kindergarten is an educational service for an early childhood. There are many activities that can stimulate children's ability in kindergarten, there are religious-morals value, social-emotional, physical motor, language, cognitive, and art. For the cognitive value, one of them is mathematical learning. For an early childhood, mathematical learning is done without coercion and not teach in a hurry methods, but it is done in a fun way to attract the children. Teachers as educators must also have the ability that qualified in teaching and in making the learning materials. However, the fact are teachers thought that teaching math for early childhood is difficult, learning looks unattractive and not challenging because the teachers limited the creativity just by introducing the numbers. This research consist some of indicators, there are indicator by the curriculum component it's consist a content, process, environment / material and center of interest of the child, indicator by the instruction component it's consist an experience planning, interaction, class management and involving parents, indicator by the assessment component it's consist to benefiting the children, observing and listening the children, using various of sources, and children's assesment learning and development. Based on the data results, the percentage of overall indicators of teacher's ability in teaching math is $78.1 \%$ with "quite conducive" category. The highest percentage was in the indicator of observation and listening the children $81.1 \%$ with "conducive" category, while the lowest percentage was in the indicator of parent involvement $71 \%$ with "quite conducive" category.
\end{abstract}

Kata kunci: Kindergarten Teacher's Ability in Teaching Math

\section{KEMAMPUAN MENGAJAR MATEMATIKA GURU TAMAN KANAK-KANAK DI TK PEMBINA SE-KOTA PEKANBARU}

\author{
Yeni Solfiah
}

\begin{abstract}
ABSTRAK
Taman Kanak-kanak merupakan layanan pendidikan yang ditujukan untuk anak usia dini. Di dalamnya terdapat berbagai kegiatan yang menstimulasi aspek yaitu moral agama, sosial-emosional, fisik motorik, bahasa, kognitif, dan seni. Untuk aspek kognitif, salah satu di dalamnya terdapat pembelajaran
\end{abstract}


matematika. Pembelajaran matematika anak usia dini dilakukan dengan tanpa paksaan dan tidak tergesa-gesa dalam mengajarkannya, melainkan dilakukan dengan cara yang menyenangkan sehingga menarik minat anak. Guru sebagai tenaga pendidik pun harus memiliki kemampuan yang mumpuni dalam mengajarkan dan membuat bahan ajar saat pembelajaran matematika. Namun, kenyataannya masih ada tenaga pendidik yang beranggapan mengajarkan matematika untuk anak usia dini itu adalah sesuatu hal yang sulit, pembelajaran pun terlihat tidak menarik dan menantang karena guru seolah membatasi kreativitas hanya sebatas mengenalkan lambang bilangan. Dalam penelitian ini dibahas beberapa indikator, yaitu indikator dari komponen kurikulum terdiri dari konten, proses, lingkungan/material dan pusat minat anak, indikator dari komponen instruksi terdiri dari perencanaan pengalaman, interaksi, pengelolaan kelas dan melibatkan orang tua, indikator dari komponen asesmen terdiri dari menguntungkan anak, observasi dan mendengarkan anak, menggunakan berbagai sumber, serta asesmen pembelajaran dan perkembangan anak. Berdasarkan hasil pengolahan data, diperoleh persentase keseluruhan indikator kemampuan mengajar matematika guru yaitu 78.1\% dengan kategori "cukup kondusif". Adapun persentase tertinggi berada pada indikator observasi dan mendengarkan anak yaitu 81.1\% dengan kategori "kondusif", sedangkan persentase terendah berada pada indikator keterlibatan orang tua yaitu $71 \%$ dengan kategori "cukup kondusif".

Kata kunci: Kemampuan Mengajar Matematika Guru TK

\section{PENDAHULUAN}

\section{Latar Belakang Masalah}

Taman kanak-kanak merupakan salah satu layanan bagi anak usia dini. Dimana rentang usia anak yang dilayani berada pada usia 4-6 tahun. Rentang usia ini membedakan kelas, untuk usia 4-5 tahun diberi nama kelas nol kecil atau kelas A. Sedangkan untuk usia 5-6 tahun diberi nama kelas nol besar atau kelas B.

Melalui taman kanak-kanak, anak usia dini mendapatkan kesempatan untuk bersosialisasi dengan teman sebaya, mendapatkan stimulasi-stimulasi melalui kegiatan bermain sambil belajar dan mengembangkan kemampuan secara maksimal. Adapun beberapa kemampuan itu seperti bahasa, kognitif, sosial-emosional, fisik motorik, dan nilai-nilai agama dan moral. Salah satu kemampuan yang distimulasi adalah kognitif. Adapun komponen bidang pengembangan kognitif terdiri dari beberapa pengembangan diantaranya adalah sains permulaan, taktil, auditori, kinestetik dan matematika. Dari beberapa pengembangan ini, matematika menempati tempat yang penting.

Pengembangan beberapa kemampuan ini membutuhkan kehadiran guru. Kehadiran guru dalam pendidikan anak usai dini merupakan hal yang penting. Guru juga diharapkan mampu menstimulasi berbagai potensi anak. Salah satunya adalah pembelajaran matematika. Menurut Eliason dan Jenkins (2012) pembelajaran matematika yang berkualitas tinggi sebaiknya menantang dan menyenangkan bagi anak. Sebaliknya pengajaran matematika untuk anak usia dini tidak dengan tekanan. 
Oleh karena itu guru taman kanak-kanak dalam mengajar matematika sebaiknya lebih luas dan dalam dari pada sekedar berhitung dan penambahan.

Matematika untuk anak tidak sekedar bisa mengenal angka dan mengoperasikannya. Namun lebih kompleks dari itu. Matematika untuk anak dapat berupa pemecahan masalah, rutinitas sehari-hari, nyata dan dilakukan dengan bermain sambil belajar. Dapat dikatakan bahwa mengajar matematika kepada anak memerlukan proses dan tanpa harus tergesa-gesa. Hal yang sama disampaikan oleh Hoorn (2007) bahwa jika guru dan orang tua terlalu terburu-buru mengajarkan matematika kepada anak maka kemampuan anak akan berkurang dan mengakibatkan frustasi. Oleh karena itu sebaiknya guru dan orang tua mengembangkan kemampuan matematika anak secara bertahap. Sehingga anak akan merasakan proses pengembangan matematika dan memberikan hasil yang optimal.

Selain itu sebagian guru merasa matematika merupakan bidang studi yang sulit. Hal ini mempengaruhi rasa percaya diri dalam mengajar matematika bagi anak. Sehingga hal ini menyebabkan guru kurang mampu melaksanakan pengajaran matematika. Selanjutnya, bila hal ini berlangsungnya terus-menerus akan berdampak pada anak usia dini yang merupakan pusat pendidikan.

Berdasarkan beberapa uraian di atas maka peneliti mengganggap penting untuk meneliti kemampuan mengajar matematika guru Taman Kanak-kanak di TK Pembina se-Kota Pekanbaru.

\section{Rumusan Masalah}

Adapun perumusan masalah dalam penelitian ini adalah bagaimana pengajaran matematika oleh guru di TK Pembina se-Kota Pekanbaru Riau?

\section{Tujuan Penelitian}

Tujuan umum penelitian ini adalah untuk mengetahui gambaran pengajaran matematika yang diberikan oleh guru di TK Pembina se-Kota Pekanbaru.

\section{Kontribusi Penelitian}

Sebagai sumber informasi tentang pentingnya pengajaran matematika untuk anak TK dan sumbangan pemikiran bagi FKIP Universitas Riau sebagai lembaga penyelenggara LPTK sehingga mampu menghasilkan calon guru PAUD yang kompeten di bidangnya. Terutama dalam menghasilkan calon-calon guru PAUD yang menguasai pengajaran matematika.

\section{Kajian Teori Hakikat Guru}

Setiap hari anak taman kanak-kanak datang ke sekolah dan mengikuti proses belajar mengajar yang diberikan oleh guru. Menjadi seorang guru taman kanak-kanak berarti siap menjadi seorang fasilitator dan motivator bagi anak. Dengan kata lain menurut Dadi Permadi dan Daeng Arifin (2013) seorang guru juga berperan memberi kemudahan belajar kepada anak dalam suasana yang menyenangkan. Seorang guru taman kanak-kanak harus mampu menstimulasi kemampuan anak. Diantaranya adalah kemampuan bahasa, motorik, kognitif, sosial-emosi dan nilai- 
nilai agama dan moral. Kemampuan kognitif terdiri dari beberapa aspek. Diantaranya adalah sains permulaan dan matematika. Pengembangan kemampuan matematika bagi anak usia dini menjadi penting karena pengalaman yang diperolehnya akan menjadi pondasi bagi jenjang pendidikan selanjutnya. Misalnya kemampuan mengenal bentuk geometri. Pada jenjang anak usia dini, mereka hanya dikenalkan dasar-dasar bentuk geometri. Seperti contoh segi empat, segi tiga dan lingkaran.

\section{Hakikat Pengajaran Matematika}

Bagi anak usia dini matematika ada dimana-mana. Matematika ada di rumah, jam dinding, telepon, buku dan mobil. Selain itu matematika juga ada di dalam lagulagu yang biasa dinyanyikan bersama guru, bermain jari, puisi dan sajak. masa ini merupakan masa yang tepat melibatkan anak dengan matematika. Sejalan dengan hal tersebut Eliason dan Jenkins (2012) menyatakan bahwa masa usia dini merupakan pondasi yang kuat untuk pemahaman, pengetahuan, kemampuan, pemecahan masalah dan kepercayaan positif mengenai matematika. Oleh karena itu guru TK sebaiknya mengenalkan matematika seperti pengembangan kemampuan yang lain.

\section{Dimensi-dimensi Pengajaran Matematika}

Anak usia dini merupakan individu yang potensial dalam pembelajaran matematika. Hal ini didukung oleh karakteristik anak usia dini yang memiliki rasa ingin tahu yang tinggi. Menurut Copley (2001) pengajaran matematika terdiri dari tiga komponen. Adapun komponen tersebut adalah kurikulum, instruksi dan asesmen.

Bila dijabarkan lebih lanjut maka indikator dari komponen kurikulum terdiri dari konten, proses, lingkungan/material dan pusat minat anak. Konten yang perlu dipersiapkan guru dalam mengajar matematika sebaiknya kaya, bervariasi dan relevan dengan kehidupan sehari-hari anak. Selanjutnya proses belajar mengajar matematika sebaiknya memecahkan masalah, mencari sebab-akibat, mengkomunikasikannya, membuat hubungan dan representatif. Lingkungan fisik dan material dalam mengajar matematika merupakan hal yang paling mendasar dalam penyusunan kurikulum matematika. Pengambilan keputusan kurikulum matematika bagi anak sebaiknya mempertimbangkan pengetahuan, kemampuan dan minat anak.

Sementara itu indikator dari komponen instruksi terdiri dari perencanaan pengalaman, instruksi, pengaturan kelas dan melibatkan orang tua. Untuk merencanakan pengalaman yang efektif guru harus membuat keputusan berdasarkan pengetahuannya dan berdasarkan kebutuhan anak. Selanjutnya selama proses belajar mengajar matematika sebaiknya guru memberikan kesempatan kepada anak untuk memecahkan masalah. Seperti contoh ketika anak menyusun menara balok, biarkan anak menyelesaikan sendiri menaranya. Sehingga proses menyusun menara yang tinggi atau yang pendek dapat dimengerti anak. pengelolaan kelas yang dibuat oleh guru juga membuat mengajar matematika efektif. Adapun pengelolaan itu berupa kegiatan-kegiatan, jadwal, proyek, lingkungan fisik dan fasilitas dalam belajar matematika. orang tua juga memiliki peran yang penting dalam mengajar matematika 
kepada anak-anaknya. Untuk itu guru PAUD mampu memfasilitasi hubungan yang timbal-balik dengan orang tua.

Adapun indikator dari komponen asesmen adalah menguntungkan, mengamati dan mendengarkan, menggunakan berbagai sumber dan asesmen pembelajaran dan perkembangan anak. Asesmen yang dilaksanakan guru selama proses belajar mengajar berlangsung dapat berupa observasi, mengajukan pertanyaan, mendengarkan dan mengamati anak menyelesaikannya. Salah satu kemampuan yang harus dimiliki guru PAUD dalam melakukan asesmen adalah mengamati dan mendengarkan anak. Selanjutnya proses asesmen dilakukan dengan mengumpulkan bukti tentang pengetahuan, kemampuan untuk menggunakan dan sikap anak terhadap matematika. Selain itu guru memiliki tanggung jawab untuk mengasesmen seberapa efektif pengajaran matematika yang dilakukan dan pengembangan anak di bidang matematika.

Dari beberapa pendapat di atas maka dapat digambarkan bahwa pengajaran matematika untuk anak usia dini terdiri dari tiga komponen. Masing-masing komponen tersebut sebaiknya diterapkan oleh guru PAUD dalam mengajar matematika. Mengingat matematika merupakan bidang studi penting dan berhubungan dengan kehidupan sehari-hari. Pengajaran matematika yang diberikan guru PAUD menjadi dasar bagi anak di jenjang pendidikan selanjutnya.

\section{Pengertian Anak Usia Dini}

Ada beberapa pendapat yang menyatakan definisi tentang anak usia dini. Salah satunya adalah NAEYC (National Association for the Education of Young Children) sebuah organisasi yang didirikan pada tahun 1926 di Washington, DC. Menurut organisasi ini anak usia dini adalah anak yang berada pada rentang usia 0-8 tahun. Anak Usia Dini menurut pendapat ini dapat mengikuti pendidikan pada jalur informal (keluarga), pendidikan pra sekolah (KB/TPA), TK dan SD awal (kelas I, II, dan III).

Sementara itu berbeda dengan yang tertulis dalam SISDIKNAS UU No.20 Tahun 2003 tentang sistem pendidkan nasional berkaitan dengan anak usia dini pada pasal 28 ayat 1 yang berbunyi "Pendidikan Anak Usia Dini diselenggarakan bagi anak sejak lahir sampai enam tahun dan bukan merupakan prasyarat untuk mengikuti pendidikan dasar". Berdasarkan UU tersebut maka Anak Usia Dini adalah anak yang berada pada rentang usia 0-6 tahun. Anak usia dini menurut pendapat ini dapat mengikuti pendidikan pada jalur informal (keluarga), pendidikan pra sekolah (KB/TPA), dan TK.

\section{Pengertian Matematika}

Seiring dengan perkembangan teknologi, matematika pun berkembang pesat. Sehingga pengertian dan definisi matematika juga mengalami perkembangan. Beberapa ahli mendefinisikan matematika dari berbagai sudut pandang. Dengan kata lain tidak terdapat satu definisi tunggal dan disepakati oleh semua pakar matematika. Jika melihat definisi dari bahasa, matematika berasal dari bahasa Latin manthanein atau mathema yang bermakna belajar atau yang dipelajari. Dalam bahasa Belanda disebut wiskunde atau ilmu pasti yang semuanya berkaitan dengan penalaran. Berdasarkan dari makna kedua kata tersebut maka dapat digambarkan bahwa 
matematika merupakan hal yang paling mendasar dalam kehidupan manusia. Selanjutnya Crystall (1994) menyebutkan bahwa "mathematics is a systematic body of knowledge built an certain axioms and assumption, principally relating to numbers and spatial relation". Menurut pendapat tersebut matematika merupakan ilmu pengetahuan yang sistematis dan dapat membangun aksioma-aksioma tertentu dan juga asumsi, terutama yang berhubungan dengan angka dan spatial.

Berdasarkan beberapa uraian di atas maka dapat digambarkan bahwa matematika merupakan hal yang paling mendasar dalam kehidupan sehari-hari manusia. Dikatakan demikian karena rutinitas yang dilakukan oleh manusia selalu menggunakan matematika untuk menyelesaikannya. Seperti contoh dalam memasangkan sepatu, sarung tangan, anting-anting dan sebagainya. Masalah ini merupakan bagian dari korespondesi satu-satu. Dimana hal ini merupakan dasar dari matematika.

\section{Matematika untuk Anak Usia Dini}

Setiap saat dalam kehidupan anak usia dini selalu berhubungan dengan matematika. Ketika anak bangun tidur maka akan menemukan konsep waktu (bilangan). Selanjutnya ketika anak melihat lampu lalu lintas maka akan menemukan konsep pola. Ketika anak menyusun balok dan menyatakan bahwa tumpukan baloknya paling tinggi, maka muncul konsep pengukuran.

Matematika menurut Brewer (2007) adalah cara anak untuk melihat dunia dan pengalaman-pengalaman di dalamnya. ${ }^{i}$ Menurut pendapat ini matematika adalah sarana bagi anak untuk memahami dunia melalui pengalaman yang nyata. Sehingga bila anak dilibatkan secara langsung dengan matematika, maka anak akan dengan mudah memahami konsep matematika dengan baik.

Selanjutnya matematika menurut Feeney (2006) adalah jalan untuk menyusun pengalaman ke bentuk ide tentang jumlah logika dan hubungan ruang antara benda, orang dan kejadian. Menurut pendapat ini matematika adalah cara anak untuk menyusun pengalaman tentang logika dan hubungannya dengan benda, orang dan kejadian di sekitar anak. Berdasarkan ketiga pendapat di atas maka dapat diambil sebuah gambaran bahwa matematika merupakan sesuatu yang diperoleh anak dari lingkungannya melalui pengalaman langsung sehingga terbentuk logika serta hubungannya dengan benda, orang dan kejadian-kejadian.

\section{Pembelajaran Matematika}

Anak usia dini merupakan individu yang potensial dalam pembelajaran matematika. Hal ini didukung oleh karakteristik anak usia dini yang memiliki rasa ingin tahu yang tinggi. Menurut Copley (2001) pengajaran matematika terdiri dari tiga komponen. Adapun komponen tersebut adalah kurikulum, instruksi dan asesmen.

Bila dijabarkan lebih lanjut maka indikator dari komponen kurikulum terdiri dari konten, proses, lingkungan/material dan pusat minat anak. Konten yang perlu dipersiapkan guru dalam mengajar matematika sebaiknya kaya, bervariasi dan relevan dengan kehidupan sehari-hari anak. Selanjutnya proses belajar mengajar matematika sebaiknya memecahkan masalah, mencari sebab-akibat, 
mengkomunikasikannya, membuat hubungan dan representatif. Lingkungan fisik dan material dalam mengajar matematika merupakan hal yang paling mendasar dalam penyusunan kurikulum matematika. Pengambilan keputusan kurikulum matematika bagi anak sebaiknya mempertimbangkan pengetahuan, kemampuan dan minat anak.

Sementara itu indikator dari komponen instruksi terdiri dari perencanaan pengalaman, instruksi, pengaturan kelas dan melibatkan orang tua. Untuk merencanakan pengalaman yang efektif guru harus membuat keputusan berdasarkan pengetahuannya dan berdasarkan kebutuhan anak. Pengelolaan kelas yang dibuat oleh guru juga membuat mengajar matematika efektif. Adapun pengelolaan itu berupa kegiatan-kegiatan, jadwal, proyek, lingkungan fisik dan fasilitas dalam belajar matematika. orang tua juga memiliki peran yang penting dalam mengajar matematika kepada anak-anaknya. Untuk itu guru PAUD mampu memfasilitasi hubungan yang timbal-balik dengan orang tua.

Adapun indikator dari komponen asesmen adalah menguntungkan, mengamati dan mendengarkan, menggunakan berbagai sumber dan asesmen pembelajaran dan perkembangan anak. Asesmen yang dilaksanakan guru selama proses belajar mengajar berlangsung dapat berupa observasi, mengajukan pertanyaan, mendengarkan dan mengamati anak menyelesaikannya. Selanjutnya proses asesmen dilakukan dengan mengumpulkan bukti tentang pengetahuan, kemampuan untuk menggunakan dan sikap anak terhadap matematika. Selain itu guru memiliki tanggung jawab untuk mengasesmen seberapa efektif pengajaran matematika yang dilakukan dan pengembangan anak di bidang matematika.

Dari beberapa pendapat di atas maka dapat digambarkan bahwa pengajaran matematika untuk anak usia dini terdiri dari tiga komponen. Masing-masing komponen tersebut sebaiknya diterapkan oleh guru PAUD dalam mengajar matematika. Mengingat matematika merupakan bidang studi penting dan berhubungan dengan kehidupan sehari-hari. Pengajaran matematika yang diberikan guru PAUD menjadi dasar bagi anak di jenjang pendidikan selanjutnya.

\section{Strategi Mengajar Matematika}

Strategi mengajar matematika disusun guru bertujuan untuk meningkatkan keberhasilan dalam mencapai tujuan pembelajaran. Hal ini karena variasi strategi pembelajaran dapat meningkatkan minat, motivasi, dan kesenangan anak untuk bermain dan belajar bersama guru dan teman-temannya. Selama setahun anak dan guru berinteraksi dalam rutinitas sehingga bisa jadi kejenuhan melanda. Dengan adanya strategi mengajar yang bervariasi maka anak dan guru akan merasa jenuh. Adapun strategi mengajar matematika untuk anak usia dini menurut Kostelnik, et all (2007) strategi mengajar matematika bagi guru PAUD :

a. Mendorong otonomi intelektual dan mengembangkan keterampilan kognitif anak secara umum.

b. Mengembangkan kemampuan anak untuk keluar dari zona aman yang berkenaan dengan konsep-konsep yang tidak akurat

c. Lebih menekankan pemahaman daripada hapalan

d. Mengintegrasikan konsep sains dan matematika dalam kurikulum

e. Memperluas kosa kata anak mengenai sains dan matematika 
f. Rutinitas sehari-hari di kelas dapat dikaitkan dengan sains dan matematika.

g. Mengembangkan sikap belajar positif dan pengalaman di kelas

h. Gunakan berbagai koleksi sebagai cara untuk memperluas dan menilai kemampuan anak untuk mengkategori, mengklasifikasikan dan menampilkan informasi.

\section{Ruang Lingkup Mengajar Matematika untuk Guru PAUD}

Matematika memiliki peranan penting dalam berbagai kondisi kehidupan. Adapun ruang lingkup matematika Untuk AUD Menurut NCTM (National Council of Teacher of Mathematics) dalam Henniger (2013) adalah sebagai berikut:

a. Angka

b. Pola dan Hubungannya

c. Geometri dan Kemampuan Ruang

d. Pengukuran

e. Pengumpulan, Organisasi dan Penyajian Data

\section{Tahapan Belajar Matematika AUD}

Berinteraksi dengan matematika memerlukan sebuah proses yang tidak singkat. Oleh karena matematika adalah sesuatu yang sistematis maka dalam mempelajarinya juga terdiri dari beberapa tahapan. Dalam memandang proses belajar matematika Bruner membagi perkembangan anak melalui tiga tahap (1) enaktif, (2) ikonik, (3) simbolik. Untuk dapat menentukan tahapan belajar tersebut Bruner melihat pada lingkungan anak. Tahapan enaktif ditandai dengan aktivitas untuk mengenali lingkungan dengan menggunakan pengetahuan motorik seperti melalui gigitan, sentuhan, pegangan, dan sebagainya.

Selanjutnya pada tahapan ikonik anak berusaha memahami objek-objek atau dunia melalui gambar atau visualisasi verbal. Maksud dalam memahami lingkungan sekitar anak belajar melalui bentuk perumpamaan yang tampil dan melalui aktivitas perbandingan. Tahapan yang terakhir adalah simbolik. Pada tahapan ini anak sudah memiliki ide-ide atau gagasan-gagasan abstrak yang sangat dipengaruhi oleh kemampuan bahasa dan logika. Dalam memahami lingkungan sekitar anak akan belajar melalui simbol bahasa, logika, matematika dan sebagainya.

\section{METODE PENELITIAN}

Penelitian ini dilakukan dengan menggunakan metode deskriptif pendekatan kuantitatif untuk memperoleh gambaran pengajaran matematika oleh guru untuk PAUD. Sejalan dengan pendapat Sugiyono (2008) penelitian deskriptif adalah penelitian yang dilakukan terhadap variabel mandiri, yaitu tanpa pembanding atau penghubung dengan variabel lain. Penelitian deskriptif bertujuan menggambarkan secara sistematik, akurat, fakta dan karakteristik mengenai populasi atau mengenai bidang tertentu.

Adapun data pada penelitian ini diperoleh melalui observasi terdiri dari 35 item. Skor obseravasi kemampuan mengajar matematika guru di setiap item meliputi rentang $5,4,3,2,1$. Selanjutnya teknik analisis data yang terkumpul dalam penelitian ini dianalisis dengan menggunakan rumus persentase dari Anas (2005) yaitu: 
$\mathrm{P}=\frac{f}{\mathrm{~N}} \mathbf{1 0 0} \%$

Keterangan :

$\mathrm{P}=$ Angka presentase

$\mathrm{f}=$ Frekuensi

$\mathrm{N}=$ Number of case (jumlah frekuensi/banyaknya individu)

Dengan kategori presentase sebagai berikut :

1) $>80 \% \quad:$ Kondusif/Tinggi

2) $>60 \%-<80 \% \quad$ : Cukup Kondusif/Cukup Tinggi

3) $>40 \%-<60 \% \quad$ : Kurang Kondusif/Rendah

4) $<40 \% \quad$ : Tidak Kondusif/Rendah

\section{HASIL DAN PEMBAHASAN PENELITIAN}

Berdasarkan hasil pengujian yang telah dilakukan, maka penulis akan memaparkan dan melakukan pembahasan hasil penelitian bahwa indikator kemampuan mengajar matematika guru terdiri dari kompetensi kepribadian yang mempunyai indikator yaitu konten, proses, lingkungan dan bahan ajar, pilihan berpusat pada anak, perencanaan pembelajaran, interaksi dengan anak, pengolahan kelas, keterlibatan orang tua, menguntungkan anak, observasi dan mendengarkan anak, menggunakan berbagai bukti, asesmen pembelajaran dan perkembangan.

Adapun data kemampuan mengajar matematika guru di Taman Kanak-kanak Pembina se-Kota Pekanbaru untuk skor Empirik dan skor Hipotetik dapat dilihat pada tabel berikut ini:

1. Skor Empirik

Descriptive Statistics

\begin{tabular}{|l|r|r|r|r|r|}
\hline & $\mathrm{N}$ & Minimum & Maximum & Mean & $\begin{array}{c}\text { Std. } \\
\text { Deviation }\end{array}$ \\
\hline $\begin{array}{l}\text { Kemampuan Mengajar } \\
\text { matematika guru } \\
\text { Valid N (listwise) }\end{array}$ & 30 & 78.00 & 164.00 & 136.6000 & 20.78063 \\
\hline
\end{tabular}

2. Skor Hipotetik

Descriptive Statistics

\begin{tabular}{|c|c|c|c|c|c|}
\hline & $\mathrm{N}$ & Minimum & Maximum & Mean & $\begin{array}{c}\text { Std. } \\
\text { Deviation }\end{array}$ \\
\hline $\begin{array}{c}\text { Kemampuan Mengajar } \\
\text { matematika guru } \\
\text { Valid N (listwise) }\end{array}$ & 30 & 35.00 & 175.00 & 105.000 & 23.33 \\
\hline
\end{tabular}

$\mathrm{X} \max =$ nilai tertinggi $\mathrm{x}$ jumlah item

$=5 \times 35$

$=175$

$\mathrm{Xmin}=$ nilai terendah $\mathrm{x}$ jumlah item 
$=1 \times 35$

$=35$

Mean $=1 / 2$ (nilai terendah + nilai tertinggi) $\mathrm{x}$ jumlah item

$=1 / 2(1+5) \times 35$

$=105$

$\mathrm{SD}=1 / 6(\mathrm{Xmax}-\mathrm{Xmin})$

$=1 / 6(175-35)$

$=23,33$

Sangat Sesuai $=\{$ Mean $+(1,5 \mathrm{SD})\} \leq \mathrm{X}$

Sesuai $=\{$ Mean $+(0,5 \mathrm{SD})\} \leq \mathrm{X}<\{$ Mean $+(1,5 \mathrm{SD})\}$

Cukup Sesuai $=\{$ Mean $-(0,5 \mathrm{SD})\} \leq \mathrm{X}<\{$ Mean $+(0,5 \mathrm{SD})\}$

Kurang Sesuai $=\{$ Mean-(1,5 SD $)\} \leq X<\{$ Mean- $(0,5$ SD $)\}$

Tidak Sesuai $=\mathrm{X}<\{$ Mean- $(1,5 \mathrm{SD})\}$

Sangat Sesuai $=140 \leq \mathrm{X}$

Sesuai $\quad=117 \leq \mathrm{X}<140$

Cukup Sesuai $=93 \leq \mathrm{X}<117$

Kurang Sesuai $\quad=70 \leq \mathrm{X}<93$

Tidak Sesuai $=\mathrm{X}<70$

Berdasarkan tabel 1 di atas dapat diketahui bahwa perolehan skor terendah dari kemampuan mengajar matematika guru di Taman Kanak-kanak Kota Pekanbaru yaitu 35, sedangkan perolehan skor tertinggi dari kemampuan mengajar matematika guru yaitu 175, sehingga diperoleh rata-rata 105. Adapun Standar Deviasi dari kemampuan mengajar matematika guru di Taman Kanak-kanak Kota Pekanbaru yaitu 23.33. Selanjutnya, persentase skor empirik dan skor hipotetik dari kemampuan mengajar matematika guru di Taman Kanak-kanak Kota Pekanbaru dikelompokkan dalam 5 kategori, yaitu sangat sesuai, sesuai, cukup sesuai, kurang sesuai, dan tidak sesuai. Untuk gambaran yang lebih jelas dapat dilihat pada tabel berikut:

\begin{tabular}{|c|l|c|c|c|}
\hline \multirow{2}{*}{ No } & \multicolumn{2}{|c|}{ Kategori } & \multirow{2}{*}{ Jumlah Subjek } & \multirow{2}{*}{ Rata-Rata } \\
\cline { 2 - 3 } & \multicolumn{1}{|c|}{ Kelompok } & Skor & & $50 \%$ \\
\hline 1 & Sangat Sesuai & $140 \leq \mathrm{X}$ & 15 & $30 \%$ \\
\hline 2 & Sesuai & $117 \leq \mathrm{X}<140$ & 9 & $17 \%$ \\
\hline 3 & Cukup sesuai & $93 \leq \mathrm{X}<117$ & 5 & $3 \%$ \\
\hline 4 & Kurang Sesuai & $70 \leq \mathrm{X}<93$ & 1 & $0 \%$ \\
\hline 5 & Tidak Sesuai & $\mathrm{x}<70$ & 0 & $100 \%$ \\
\hline & \multicolumn{2}{|c}{ Jumlah } & 30 & \\
\hline
\end{tabular}

Gambar tabel di atas merupakan persentase skor empirik dan skor hipotetik kemampuan mengajar matematika guru di TK Pembina se-kota Pekanbaru. Berdasarkan tabel tersebut dapat diketahui skor dari indikator kemampuan mengajar matematika guru di TK Pembina se-Kota Pekanbaru sebanyak 30 guru memperoleh persentase dengan rincian yaitu 50\% (15 guru) dengan kategori "sangat sesuai", 30\% (9 guru) dengan kategori "sesuai", 17\% (5 guru) dengan kategori "cukup 
sesuai", dan 3\% (1 guru) dengan kategori "kurang sesuai". Dengan demikian dapat dikatakan bahwa rata-rata kemampuan mengajar matematika guru di TK Pembina kota Pekanbaru berada pada kategori "sangat sesuai".

Adapun data skor indikator kemampuan mengajar matematika guru di TK Pembina se-Kota Pekanbaru dapat dilihat pada tabel berikut ini:

Tabel 3. Tabel Skor Indikator Kemampuan Mengajar Matematika Guru

\begin{tabular}{|c|c|c|c|c|c|c|}
\hline No & Indikator & $\begin{array}{c}\text { Jumlah } \\
\text { Item }\end{array}$ & $\begin{array}{l}\text { Skor } \\
\text { Faktual }\end{array}$ & $\begin{array}{l}\text { Skor } \\
\text { Ideal }\end{array}$ & $\begin{array}{c}\text { Rata- } \\
\text { rata }\end{array}$ & Persentase \\
\hline 1 & Konten & 3 & 356 & 450 & 11,9 & $79,1 \%$ \\
\hline 2 & Proses & 3 & 361 & 450 & 12,0 & $80,2 \%$ \\
\hline 3 & $\begin{array}{l}\text { Lingkungan dan Bahan } \\
\text { Ajar }\end{array}$ & 2 & 241 & 300 & 8,0 & $80,3 \%$ \\
\hline 4 & $\begin{array}{l}\text { Pilihan Berpusat Pada } \\
\text { Anak }\end{array}$ & 3 & 350 & 450 & 11,7 & $77,8 \%$ \\
\hline 5 & $\begin{array}{l}\text { Perencanaan } \\
\text { Pembelajaran }\end{array}$ & 4 & 484 & 600 & 16,1 & $80,7 \%$ \\
\hline 6 & Interaksi dengan Anak & 3 & 360 & 450 & 12,0 & $80 \%$ \\
\hline 7 & Pengelolaan Kelas & 3 & 344 & 450 & 11,5 & $76,4 \%$ \\
\hline 8 & Keterlibatan Orang Tua & 2 & 213 & 300 & 7,1 & $71 \%$ \\
\hline 9 & Menguntungkan Anak & 3 & 329 & 450 & 11,0 & $73,1 \%$ \\
\hline 10 & $\begin{array}{l}\text { Observasi dan } \\
\text { Mendengarkan Anak }\end{array}$ & 3 & 365 & 450 & 12,2 & $81,1 \%$ \\
\hline 11 & $\begin{array}{l}\text { Menggunakan Berbagai } \\
\text { Bukti }\end{array}$ & 3 & 346 & 450 & 11,5 & $76,9 \%$ \\
\hline 12 & $\begin{array}{l}\text { Asesmen Pembelajaran } \\
\text { dan Perkembangan }\end{array}$ & 3 & 349 & 450 & 11,6 & $77,6 \%$ \\
\hline & Jumlah & 35 & 4098 & 5250 & 11,4 & $78,1 \%$ \\
\hline
\end{tabular}

Sumber: Data olahan penelitian, lampiran 9

Berdasarkan Tabel 3 di atas dapat diketahui bahwa skor dari indikator kemampuan mengajar matematika guru di TK Pembina se-Kota Pekanbaru sebanyak 30 guru memperoleh persentase rata-rata sebesar 78,1\%. Adapun rincian perolehan persentase per indikator kemampuan mengajar matematika guru di TK Pembina se-Kota Pekanbaru yaitu untuk indikator konten diperoleh persentase 79.1\% dengan kategori “cukup kondusif”, untuk indikator proses diperoleh persentase 80.2\% dengan kategori "kondusif", untuk indikator lingkungan dan bahan ajar diperoleh persentase $80.3 \%$ dengan kategori "kondusif', untuk indikator pilihan berpusat pada anak diperoleh persentase $77.8 \%$ dengan kategori "cukup kondusif', untuk indikator perencanaan pembelajaran diperoleh persentase $80.7 \%$ dengan kategori "kondusif', untuk indikator interaksi dengan anak diperoleh persentase 80\% dengan kategori "kondusif', untuk indikator pengelolaan kelas diperoleh persentase $76.4 \%$ dengan kategori "cukup kondusif', untuk indikator keterlibatan orang tua diperoleh persentase 71\% dengan kategori “cukup kondusif”, untuk indikator menguntungkan anak diperoleh persentase $73.1 \%$ dengan kategori "cukup kondusif', untuk indikator observasi dan mendengarkan anak diperoleh persentase $81.1 \%$ dengan kategori "kondusif", untuk indikator menggunakan 
berbagai bukti diperoleh persentase 76.9\% dengan kategori "cukup kondusif', untuk indikator asesmen pembelajaran dan perkembangan diperoleh persentase $77.6 \%$ dengan kategori "cukup kondusif”.

Berdasarkan hasil penelitian diketahui bahwa kemampuan mengajar matematika guru di TK Pembina se-Kota Pekanbaru yang menunjukkan angka 78.1\% dengan kategori “cukup kondusif'. Ini menunjukkan bahwa secara keseluruhan berdasarkan 12 indikator yang tercantum di atas, kemampuan mengajar matematika guru di TK Pembina se-Kota Pekanbaru terbilang cukup kondusif. Adapun persentase terendah berada pada indikator keterlibatan orang tua yaitu 71\% dengan kategori "cukup kondusif', sedangkan persentase tertinggi terdapat pada indikator observasi dan mendengarkan anak yaitu 81.1\% dengan kategori "kondusif".

\section{SIMPULAN DAN REKOMENDASI}

\section{Simpulan}

Berdasarkan hasil analisis data dan pembahasan, maka dapat disimpulkan sebagai berikut:

a. Guru di TK Pembina se-Kota Pekanbaru yang berjumlah 30 orang, 50\% (15 orang) di antaranya termasuk dalam kategori "sangat sesuai" dalam hal kemampuan mengajar matematika untuk anak usia dini, namun masih terdapat 17\% (5 orang) yang dikategorikan "cukup sesuai" dan 3\% (1 orang) yang dikategorikan "kurang sesuai". Ini artinya, tidak dapat dipungkiri bahwa kemampuan matematika guru di TK Pembina se-Kota Pekanbaru belum sama merata sehingga ada di antaranya yang termasuk dalam kategori "cukup sesuai" atau bahkan "kurang sesuai".

b. Perolehan persentase secara keseluruhan indikator kemampuan mengajar guru di TK Pembina yaitu 78.1\% dengan kategori "cukup kondusif”, yang artinya secara keseluruhan kemampuan mengajar guru di TK Pembina se-Kota Pekanbaru terbilang “cukup kondusif” dilihat dari konten, proses, lingkungan dan bahan ajar, pilihan berpusat pada anak, perencanaan pembelajaran, interaksi dengan anak, pengelolaan kelas, keterlibatan orang tua, menguntungkan anak, observasi dan mendengarkan anak, menggunakan berbagai bukti, asesmen pembelajaran dan perkembangan.

\section{Rekomendasi}

Adapun rekomendasi yang dapat diberikan dari hasil penelitian ini yaitu:

a. Pentingnya pembelajaran matematika untuk anak usia dini sudah seharusnya menjadi perhatian guru untuk lebih mengasah kemampuan dalam mengajar matematika agar berjalan sesuai dengan tahapan perkembangan anak didik. Untuk itu, perlu kiranya para pendidik di TK Pembina se-Kota Pekanbaru untuk selalu memperbaharui pengetahuannya dengan mengikuti pelatihanpelatihan terkait pembelajaran matematika. 
b. Peran pemerintah Kota Pekanbaru tentunya tidak dapat dilepaskan dari pengembangan kemampuan mengajar matematika guru. Untuk itu, diharapkan peran pemerintah dalam bekerjasama dengan tenaga pendidik di seluruh TK se-Kota Pekanbaru agar pembelajaran matematika dapat berjalan kondusif tidak hanya pada satu indikator kemampuan mengajar matematika saja, melainkan diharapkan agar keseluruhan indikator dapat dicapai dengan kategori kondusif.

\section{DAFTAR PUSTAKA}

Copley, Juanita. 2001. The Young Child and Mathematics. Washington DC: NAEYC.

David Crystall. 1994. The Cambidge Encyclopedia. New York: Cambridge University Press.

Dadi Permadi dan Daeng Arifin. 2013. Panduan Menjadi Guru Profesional. Bandung: Nuansa Aulia.

Eliason, Claudia dan Loa Jenkins. 2012. A practical guide to Early Childhood Curriculum. Boston: Pearson

Henniger, Michael L. 2013. Teaching Young Children. Washington: Pearson.

Hoorn, Judith Van. 2007. Play at the center of curriculum. Ohio: Pearson.

Jo Ann Brewer. 2007. Introduction to Early Childhood Education. USA: Pearson.

Kostelnik, Anne K. Soderman dan Alice P. Whiren. 2007. Developmentally Appropriate Curriculum. New Jersey: Pearson.

Sugiyono. 2008. Metode Penelitian Pendidikan. Bandung: Alfabeta.

Stephanie Feeney, Christensen Doris and Eva Moravcik. 2006. Who Am I in The Lives of Children? New Jersey: Pearson. 